\title{
Nacionalismo, terceiro- mundismo e violência política: John William cooke e a formação do peronismo revolucionário
}

Nationalism, third-worldism and political violence: John William cooke and the rising of revolutionary Peronism

\section{Luiz Eduardo Motta*}

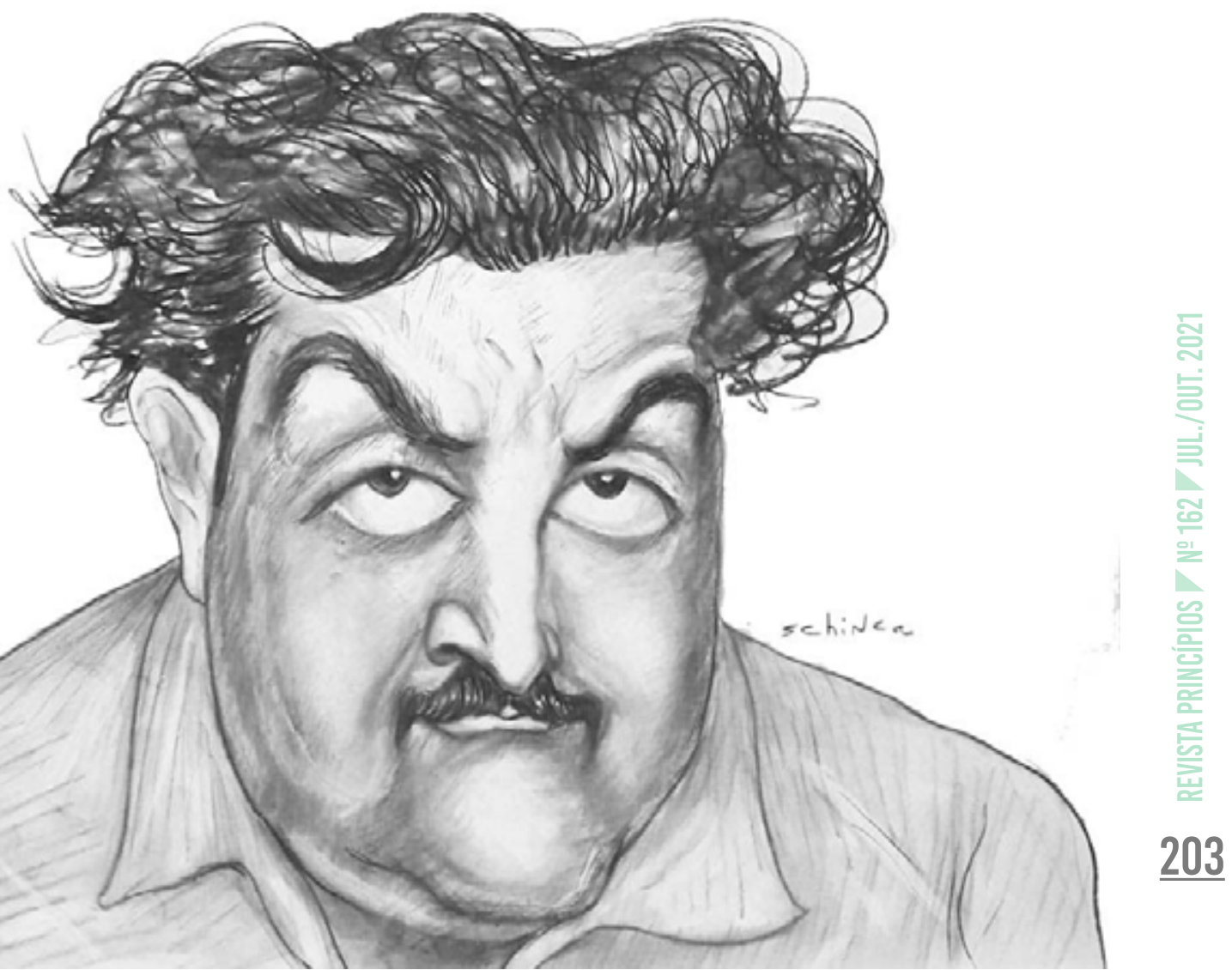




\section{RESUMO}

O presente artigo tem como objetivo analisar a obra de John William Cooke, político e pensador argentino, e uma das principais referências do peronismo de esquerda. Este trabalho terá como foco as seguintes questões tratadas por Cooke: o nacionalismo popular revolucionário, a ideologia e o movimento terceiro-mundistas, a formação do peronismo revolucionário e a práxis da violência política. Para isso, será feita uma leitura direta dos textos de Cooke e uma comparação das posições dele com a de outros pensadores e políticos que expressavam as lutas de libertação nacional do Terceiro Mundo, especialmente Frantz Fanon. Concluímos que a posição nacionalista revolucionária de Cooke formou uma ruptura no interior do peronismo ao colocar como centro do programa peronista o socialismo nacional, além de o peronismo representar na formação social argentina o principal movimento anticolonial vinculado às lutas do chamado Terceiro Mundo.

Palavras-chave: John William Cooke. Peronismo. Terceiro Mundo. Violência revolucionária. Fanon.

\section{ABSTRACT}

Argentine politician and thinker, and one of the main references of left Peronism. This work will focus on the following issues addressed by Cooke: popular revolutionary nationalism, ideology and third-world movement, the rising of revolutionary Peronism and the praxis of political violence. For that, a direct reading of Cooke's texts will be made, seeking a comparison between his positions and those of other thinkers and politicians who expressed the struggles for national liberation in the Third World, especially Frantz Fanon. We conclude that Cooke's revolutionary nationalist position formed a rupture within Peronism by placing a socialism with national character at the center of the Peronist program, in addition to representing, in Argentine social formation, the main anti-colonial movement linked to the struggles of so-called Third World.

Keywords: John William Cooke. Peronism. Third World. Revolutionary violence. Fanon. 


\section{INTRODUÇ̃̃o}

O presente artigo tem como objetivo analisar a obra de John William Cooke, político e pensador argentino, e uma das principais referências do peronismo de esquerda. Formado em Direito, Cooke começou a sua militância no peronismo nos anos 1940 e tornou-se deputado pelo Partido Justicialista. Lecionou economia política na Faculdade de Direito e Ciências Sociais da Universidade de Buenos Aires e, com o exílio de Perón em 1955 - destituído do poder por meio do golpe militar liderado pelo general Aramburu e o almirante Rojas -, tornou-se o principal representante da resistência peronista ao governo militar. Com a emergência da Revolução Cubana, em 1959, Cooke deu uma guinada à esquerda revolucionária de corte nacionalista e terceiro-mundista, começou a constituir as bases teórico-políticas do peronismo revolucionário em seus escritos e obteve grande impacto nos anos 1960 sobre a juventude argentina que ingressou nas organizações armadas peronistas no final dos anos 1960 e na década de 1970. Este trabalho terá como foco as seguintes questões tratadas por Cooke, bem como a articulação dessas problemáticas na sua obra: o nacionalismo popular revolucionário, a ideologia e o movimento terceiro-mundistas, a formação do peronismo revolucionário e a práxis da violência política. A ênfase será nos seus textos da década de 1960, em que Cooke radicalizou o seu pensamento na defesa da revolução de libertação nacional - como via para o socialismo - e do primado da violência revolucionária na prática política. Esses elementos indicam que a posição de Cooke ia ao encontro da perspectiva de ruptura revolucionária de caráter nacionalista e terceiro-mundista que esteve presente na obra de outros intelectuais - e dirigentes políticos - cujas propostas convergiam à de Cooke, como Fanon, Cabral e Nkrumah.

\section{A IDEOLOGIA NACIONALISTA POPULAR REVOLUCIONÁRIA}

O nacionalismo como expressão ideológica não tem uma definição conceitual consensual nas ciências sociais, haja vista que há no termo tanto uma conotação positiva, que identificaria um movimento político de resistência anticolonial ou anti-imperialista, como negativa, ao designar uma ideologia que embotaria a consciência da classe trabalhadora e, consequentemente, dos movimentos organizados. Esta segunda posição foi marcante na produção intelectual paulista dos anos 1960 e 1970. Francisco Weffort, em $O$ populismo na política brasileira, afirmava peremptoriamente que "não há dúvidas que o nacionalismo obscureceu gravemente o sentido de classe da emergência política das massas, a formação do proletariado no bojo do desenvolvimento capitalista" (WEFFORT, 1986, p. 39). Mais adiante, Weffort apontava uma concepção estatista (o Estado como principal elemento aglutinador e principal agente transformador) na ideologia nacionalista, não obstante esta se apresentar como uma ideologia que traduzia os "interesses gerais de todo o povo" (WEFFORT, 1986, p. 40). Como efeito disso, além de obstaculizar a formação de organizações partidárias 
No caso de uma classe

dominante (ou de frações

dominantes), ao interpelar as

classes dominadas, ela absorve

parcialmente e neutraliza os

conteúdos ideológicos por

meio dos quais se expressa a

resistência à dominação

dos próprios trabalhadores, o Estado nacionalista, ao ser visto como a encarnação da representação geral, obscureceria o seu papel de instrumento de dominação (WEFFORT, 1986, p. 42-43).

Seguindo os passos de Weffort, Maria Sylvia Carvalho Franco, em sua crítica aos intelectuais do Iseb - especialmente ao livro de Álvaro Vieira Pinto Consciência e realidade nacional —, assinalava que a ideologia nacionalista liquidava a luta de classes e promovia a burguesia nacional como protagonista do processo de mudanças na formação social brasileira:

a liquidação da luta de classes e a afirmação da unidade nacional são, ao mesmo tempo, a defesa da classe produtora autenticamente brasileira, portadora do progresso. [...] Mais uma vez se viram de cabeça para baixo os agentes da luta nacional: os interesses da burguesia passam a ser defendidos pelo proletário, e a isto - realizar fins alheios - que se costuma conceituar de alienação, A. Vieira Pinto batiza do contrário, chama libertação (FRANCO, I978, p. I78-I79).

Para essa leitura "uspiana", o nacionalismo é uma ideologia que tem uma finalidade específica em relação à classe trabalhadora, qual seja, ser um dique de contenção à sua própria consciência, que essencialmente é revolucionária e transformadora. A ideologia nacionalista dilui as contradições e antagonismos entre as classes dominantes e dominadas, e funciona em última instância a favor dos interesses dos setores dominantes (o bloco no poder) ${ }^{2}$, já que atende a seu projeto de desenvolvi-

\footnotetext{
Paradigmáticos dessa perspectiva anti-isebiana e antinacionalista são os livros de Carlos Guilherme Mota, Ideologia da cultura brasileira, e de Caio Navarro de Toledo, Iseb: fábrica de ideologias. É importante ressaltar que a posição de Caio Navarro de Toledo mudou posteriormente, em seu livro publicado em 2005, Intelectuais e política no Brasil: a experiência do Iseb. Uma posição oposta a essa perspectiva sobre a problemática do nacionalismo no Brasil, vemos em Ferreira e Reis (2007).

2 Tomamos aqui como referência esse conceito de Nicos Poulantzas. O bloco no poder é a articulação das distintas frações de classes, sob a hegemonia de uma das frações, e forma uma unidade contraditória nessa condensação de relações de força dentro e fora do Estado. Veja Poulantzas (2019).
} 
mento infraestrutural e de manutenção do poder, tendo o Estado como mola propulsora da reprodução dessa ideologia neutralizadora no seio da classe trabalhadora.

Já Laclau tem uma posição completamente distinta dessa perspectiva formulada por Weffort e Carvalho Franco. Se, para estes, a ideologia nacionalista tem um conteúdo de classe fixo (os interesses burgueses), para Laclau a ideologia nacionalista é uma forma desprovida de conteúdo. Segundo Laclau, o nacionalismo considerado em si mesmo está desprovido de uma conotação classista. $\mathrm{O}$ nacionalismo pode ser a plataforma de um projeto de expansão burguesa num espaço geográfico, a exemplo dos EUA ou da Alemanha. Mas também pode ser a base de um programa anti-imperialista e de libertação nacional, a exemplo da Revolução Chinesa de I949, ou das lutas anticoloniais africanas. O caráter de classe de um discurso ideológico se revela em seu princípio articulatório específico (LACLAU, I979, p. I66)³. Como questiona Laclau: Será que o nacionalismo se refere a conteúdos tão diversos que não seja possível identificar um elemento comum de sentido em todos eles? Ou talvez ocorra que certos núcleos comuns de sentido estejam conotativamente ligados a campos ideológico-articulatórios distintos? Se aceitarmos a primeira solução, teríamos que concluir que a luta ideológica enquanto tal é impossível, uma vez que as classes só podem competir em nível ideológico caso exista um marco comum de sentido compartilhado por todas as forças em luta.É justamente esse background de significados compartilhados que permite aos discursos antagônicos estabelecerem suas diferenças. Os discursos políticos das diversas classes, por exemplo, consistem em esforços articulatórios antagônicos, em que cada classe se apresenta como a autêntica representante do "povo", "do interesse nacional" etc. Se, por conseguinte, aceitarmos a segunda solução - que consideramos correta - será preciso concluir que as classes existem nos níveis ideológico e político, sob a forma da articulação, e não da redução (LACLAU, 1979, p. I67, grifos originais).

Isso significa que uma interpelação discursiva - a prática ideológica - de uma classe hegemônica ultrapassa os seus limites ao articular em suas interpelações elementos não classistas, ou que sejam oriundos de outras classes. Esse processo "interpelatório" não se dirige apenas aos membros dessa classe dominante, mas também aos membros das classes dominadas. No caso de uma classe dominante (ou de frações dominantes), ao interpelar as classes dominadas, ela absorve parcialmente e neutraliza os conteúdos ideológicos por meio dos quais se expressa a resistência à dominação. O método através do qual se realiza esse processo é o de eliminar o antagonismo e transformá-lo em uma simples diferença. A ideologia dominante de uma classe se dá na sua capacidade de articular elementos ideológicos de outras classes de forma tal

Neste artigo me atenho à fase inicial da obra de Laclau e sua contribuição para o conceito de populismo, que teve como marca a influência da obra de Louis Althusser, especialmente no uso dos conceitos de sobredeterminação e de ideologia como prática materializada por uma relação especular e "interpelatória". 
porar o pensamento marxista, ao qual já vinha dedicando seus estudos mesmo antes de sua ida a Cuba em 1960. Para Cooke, o nacionalismo não se restringia mais ao controle dos monopólios e à distribuição de renda, mas, como bandeira anti-imperialista, passava a incluir a defesa da "terceira posição" (que incorpora as lutas do Terceiro Mundo), e a ser considerada o caminho para o socialismo. É nesse contexto da virada dos anos I950 para a década de 1960 que Cooke começa a advogar pelo "socialismo nacional", ou nacionalismo popular revolucionário7. Nessa empreitada da construção do peronismo de esquerda, ou peronismo socialista, somaram-se a Cooke outros intelectuais oriundos do marxismo que aderiram ao peronismo ainda no primeiro governo Perón, como Juan Hernández Arregui, Jorge Abelardo Ramos e Rodolfo Puiggrós, e juntamente com Cooke criaram as bases teóricas da "esquerda nacional". Esse conjunto de intelectuais não somente internalizou, mas também radicalizou as premissas anti-imperialistas estabelecidas por Ugarte (20I0) no início do século XX.

O cerne da obra de Cooke foi produzido durante a década de 1960 e comporta a obra Informe a las bases (ou Peronismo y revolución), publicado em I966, e dois livros póstumos, publicados no início dos anos 1970: La lucha por la liberación nacional (composto de palestras realizadas em 1959, 1964 e 1967) e Apuntes para la militancia (textos escritos entre 1964 e 1965), ambos organizados pela viúva de Cooke, Alicia Eguren8. Somam-se a esses trabalhos dezenas de artigos, cartas, discursos e entrevistas realizados entre 1946 e 1967, além da vasta correspondência com Perón, de 1956 a 1966. Esses textos de Cooke são intervenções diretas naquela conjuntura política da formação social argentina: a proscrição do peronismo desde 1955 e a derrocada da resistência pe-

\footnotetext{
Sobre o socialismo nacional na Argentina, veja Galasso (2010)

Um bom exemplo de definição da ideologia nacionalista popular revolucionária é a do dirigente montonero Mario Eduardo Firmenich em depoimento ao jornalista Fernando de Morais publicado na revista Status, em janeiro de 1981. Firmenich critica a posição de certos setores da esquerda argentina que afirmavam que toda aliança entre o proletariado e setores burgueses seria necessariamente um tipo de "bonapartismo", e que todo processo nacionalista seria fascista. De acordo com o líder montonero: "a meu ver, existe uma política correta para a revolução antioligárquica e antiimperialista, que é o nacionalismo popular revolucionário, que não é o nacionalismo das oligarquias patrioteiras. O peronismo encarna esse processo e é a forma particular que adquire, em nosso país, o nacionalismo popular revolucionário a partir de meados da década de 40 . E o que é isso? É, simplesmente, uma aliança do proletariado com os camponeses e com as frações do empresariado nacional e da pequena e média burguesia, contra a aliança oligárquico-imperialista, num processo de consolidação da independência nacional em trânsito para o socialismo." (FIRMENICH, 1981, p. 61) Essa identificação com o nacionalismo popular revolucionário não foi exclusiva dos Montoneros, pois outros grupos armados também se enquadravam nessa ideologia. Na Colômbia, o Movimento 19 de Abril (M-19), que era a dissidência estudantil e da ala esquerda da Aliança Nacional Popular (Anapo), reivindicava essa ideologia. A Frente Sandinista Nacional também expressava essa ideologia, além de recorrer às lutas de tradição popular da Nicarágua, tais como as protagonizadas por Sandino, que não era comunista, mas sim um nacionalista anti-imperialista. No Brasil, quem melhor expressou essa ideologia foi o brizolismo, que, enquanto movimento, foi incorporado a diversas organizações armadas, como o Movimento Nacionalista Revolucionário (MNR), o Movimento Armado Revolucionário (MAR), a Ação Libertadora Nacional (ALN) e a Vanguarda Popular Revolucionária (VPR). Sobre o populismo e o nacionalismo de esquerda no Brasil, veja Ferreira (2017) e Ferreira e Reis (2007)

8 O volume V (2011) das obras completas de John William Cooke, intitulado Peronismo y revolución, é composto das seguintes obras: Peronismo y revolución; El peronismo y el golpe de Estado; Informe a las bases (mais conhecido pelo título Informe a las bases), La lucha por la liberación nacional e Apuntes para la militancia: peronismo critico.
} 
ronista; a fragilidade e ingovernabilidade dos governos Frondizi e Illia; a emergência da ditadura militar de Onganía, em I966, e a luta interna no peronismo. Esse conflito interno se deu entre a direita peronista representada pela burocracia sindical de Vandor (que se aproximou do governo de Onganía e era defensor da máxima "Peronismo sem Perón") e a esquerda peronista defensora do socialismo nacional, que ganhou adeptos na juventude argentina, boa parte dela oriunda das organizações cristãs de direita, como a Tacuara, que migraram para o campo da esquerda com a ascensão do Movimento de Sacerdotes para o Terceiro Mundo, identificados com a teologia da libertação. A ideologia nacionalista revolucionária apregoada por Cooke tinha como eixos o anti-imperialismo, o anticolonialismo (Cooke definia a Argentina como uma semicolônia), a posição terceiro-mundista e a violência revolucionária (a luta armada) como primado da prática política. Seu pensamento, mais do que o dos outros intelectuais argentinos do peronismo de esquerda, foi o fundamento teórico e político para as organizações armadas peronistas de esquerda que marcaram o cenário político argentino na virada dos anos I960 para I970, como as Forças Armadas Peronistas (FAP), as Forças Armadas Revolucionárias (FAR) e, sobretudo, os Montoneros9.

Em seus textos, Cooke diferenciava o que seria o verdadeiro nacionalismo (de corte revolucionário) em relação ao falso nacionalismo de direita, que se apegava aos valores simbólicos da pátria, ao hino nacional, mas na prática atendia aos interesses dos setores oligárquicos e se submetia a uma agenda imperialista ditada pelas formações sociais capitalistas desenvolvidas ${ }^{\mathrm{IO}}$. Como afirma Cooke em Informe a las bases:

No momento em que sofremos a mais aberta, total e ilimitada dominação imperialista de toda a nossa história, só se pode considerar "nacionalista" uma política que lute contra o imperialismo. E, pelo que temos relatado, a burguesia não é nem pode ser anti-imperialista [...;] o peronismo era um nacionalismo democrático burguês, popular, obreirista, e contrariava as ideias autoritárias, paternalistas, de respeito pelas "hierarquias" que tinha o nacionalismo de direita (COOKE, 20II, p. 58, tradução nossa).

O elemento central da ideologia nacionalista no discurso de Cooke, em sua demarcação com o nacionalismo presente no peronismo de direita, vem a ser a atribuição à classe trabalhadora do papel central na condução desse projeto nacional. Se o nacionalismo da direita peronista centralizava na figura da liderança de Perón a construção do projeto nacional de cima para baixo, Cooke inverteu o papel construtor

Como observa Goldar, Cooke criou uma tendência no peronismo que se definia como antiburocrática, socialista, profundamente nacional e fraterna com as lutas de libertação nacional: "atualizou o peronismo, de acordo com a realidade a ser modificada, e a tendência revolucionária cresce apoiada em seu pensamento e nas formas de luta de sua vida, com efeito multiplicador e irreversível" (GOLDAR, 2004 , p. 11, tradução nossa)

10 "O nacionalismo, plasmador das nações europeias do século XIX, a compasso com o desenvolvimento do capitalismo, deu lugar a outro nacionalismo. Um nacionalismo que rechaça as agressões do nacionalismo imperial. É o nacionalismo dos povos coloniais. Um nacionalismo que nasce dos povos e de suas tradições enterradas pelas oligarquias aliadas à Europa. Só se constrói a nação sobre o passado." (ARREGUI, 1973, p. 20-21) 


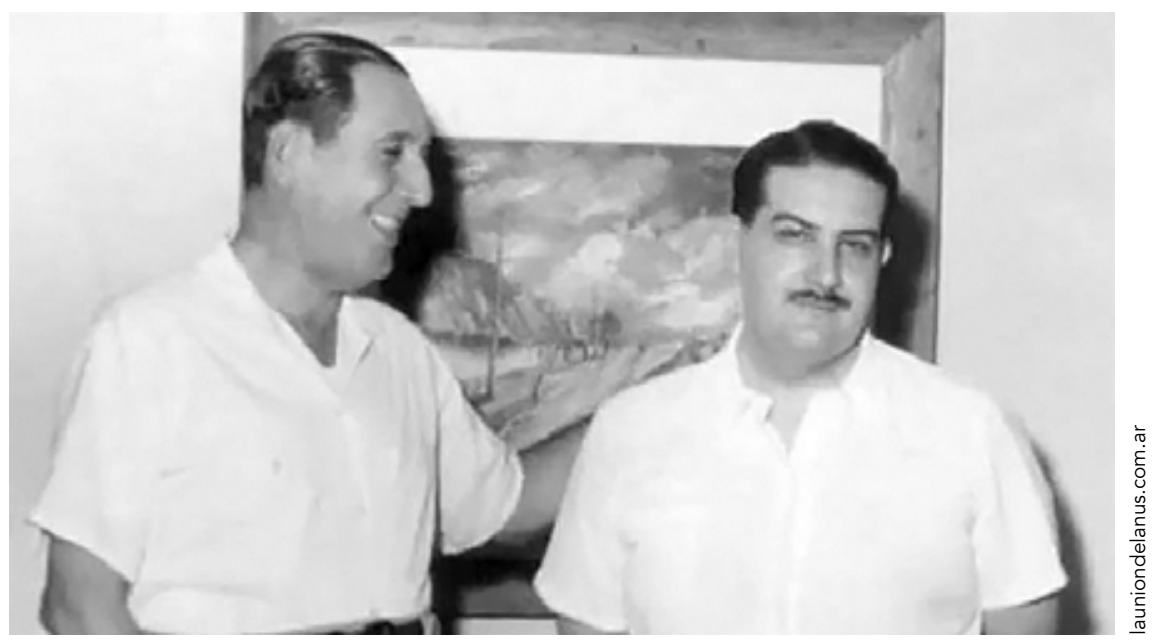

John William Cooke (dir.) ao lado do presidente argentino Juan Domingo Perón, que o nomeou procurador do Movimento Nacional Justicialista

desse projeto, pois a liderança de Perón sobre o movimento nacionalista de caráter transformador só se sustentaria com a liderança da classe trabalhadora. Em La lucha por liberación nacional, o autor observa que "não há política senão sob a condução da classe trabalhadora, e que mobilize a vontade nacional por trás do empreendimento revolucionário de mudar a ordem social existente e assegurar suas bases materiais mediante o desenvolvimento independente" (COOKE, 20II, p. 206, tradução nossa).

\section{PERONISMO REVOLUCIONÁRIO E TERCEIRO-MUNDISMO}

O nacionalismo popular revolucionário associado por Cooke ao peronismo não era insulado, já que se somava a outros movimentos de libertação nacional em andamento nas colônias e semicolônias das formações sociais dependentes. Essa ideologia nacionalista tinha um teor anti-imperialista e anticolonial de configuração reativa à dependência econômica, política e cultural, e expressava a hora e a vez do Terceiro Mundo no cenário internacional no contexto político dos anos 1960, vide o processo revolucionário anticolonial que se propagou a partir da Revolução Chinesa, de 1949, da Revolução Cubana, em 1959, e da Revolução Argelina, em I962, além da resistência vietnamita e de outras lutas que vinham sendo travadas na África e na América Latina. Numa passagem de La lucha por liberación nacional, Cooke afirma: "A pátria é o sentido do futuro, é a possibilidade nos construirmos como nação, como parte da revolução latino-americana, como parte da frente revolucionária mundial." (COOKE, 20II, p. 219, tradução nossa)

Convergentes às ideias de Cooke, no mesmo contexto, são as posições nacionalistas de Guerreiro Ramos ${ }^{\text {II }}$ Tanto Cooke como Guerreiro Ramos não definem o 


\section{Esse nacionalismo radical \\ popular presente em \\ Cooke e Guerreiro Ramos \\ se estendia a outros \\ intelectuais porta-vozes das \\ lutas anticoloniais, como \\ Fanon e Amílcar Cabral}

nacionalismo como um fim em si, mas como meio para se alcançar a soberania nacional - política, econômica e cultural - e o socialismo (neste caso, mais explícito em Cooke). Guerreiro Ramos também não dissociava o nacionalismo popular da luta de classes, como podemos ver em sua crítica a Álvaro Vieira Pinto em seu livro Mito e verdade sobre a revolução brasileira: "Para a classe operária, a união nacional contra o imperialismo é uma união com a luta de classes. Somente para o nacionalismo burguês é concebível tal união nacional sem luta de classes." (GUERREIRO RAMOS, 20I6, p. 280) E as lutas de libertação nacional eram — para Guerreiro Ramos - a expressão máxima de resistência ao imperialismo no Terceiro Mundo, o que lhes dava um caráter internacional. O nacionalismo como um meio de superação do subdesenvolvimento e da dependência. Como afirma Guerreiro Ramos,

o nacionalismo é a ideologia dos povos que, na presente época, lutam por libertar-se da condição colonial. [...] O nacionalismo é reivindicação essencial que fazem hoje os povos que não se encontram ainda em pleno gozo da soberania. [...] O nacionalismo é o único modo possível de serem hoje universalistas os povos periféricos. Somente se organizando como personalidades nacionais podem ingressar no nível da universalidade e da civilização. $\mathrm{O}$ nacionalismo não é fim. É meio. Certamente deixarão de ser nacionalistas no futuro os povos que realizarem com êxito a sua revolução nacional (GUERREIRO RAMOS, I960, p. 226).

Esse nacionalismo radical popular presente em Cooke e Guerreiro Ramos se estendia a outros intelectuais porta-vozes das lutas anticoloniais, como Fanon e Amílcar Cabral ${ }^{12}$. Era a emergência da ideologia terceiro-mundista que tanto faria frente

12 Essa articulação do nacionalismo com o marxismo não se restringiu às formações sociais do Terceiro Mundo ou a espaços com unidade estatal, durante os anos 1960 e 1970. Paradigmática do último caso foi a resistência palestina no Oriente Médio, em que a Organização para a Libertação da Palestina (OLP) abarcava diversos grupos marxistas nacionalistas, como a Frente Popular para a Libertação da Palestina, a Frente Democrática para a Libertação da Palestina e o Partido Popular da Palestina. Do primeiro caso, temos como exemplos a organização canadense Frente de Libertação do Quebec, o Exército Republicano Irlandês Oficial e o Exército Republicano Irlandês Provisório, na Irlanda, e o ETA, que aderiu ao marxismo em 1963, na Espanha. 
ao sistema capitalista e colonial como também constituiria uma alternativa política ao "socialismo real" do Leste Europeu. China e Cuba, embora estivessem sob a liderança de partidos comunistas, proclamavam pertencer ao Terceiro Mundo. O mesmo farão a Frente Nacional para a Libertação do Vietnã (FNL), o Movimento Popular de Libertação de Angola (MPLA), a Frente de Libertação de Moçambique (Frelimo) e o Partido Africano da Independência da Guiné e Cabo Verde (PAIGC). Mas a grande referência, naquele contexto, de um socialismo sem base marxista vai ser a Frente de Libertação Nacional (FLN), que liderou a Revolução Argelina e iniciou um socialismo de base nacionalista e islâmica.

A categoria Terceiro Mundo foi criada por Alfred Sauvy num artigo publicado na revista L'Observateur em 1952 para diferenciar um grupo de países não alinhados ao bloco capitalista liderado pelos EUA nem ao bloco socialista liderado pela URSS, durante o período da Guerra Fria' ${ }^{13}$. De acordo com a definição de Samir Amin:

A Segunda Guerra Mundial inaugura uma nova etapa no sistema planetário. O progresso do pós-guerra (1945-1970) se baseou na complementaridade dos três projetos societários da época, a saber: I) no Ocidente, o projeto do Estado de bem-estar ou providência da democracia social nacional, que assenta sua ação na eficácia dos sistemas produtivos nacionais interdependentes; 2) o "projeto de Bandung" de construção nacional burguesa na periferia do sistema (a ideologia do desenvolvimento); 3) finalmente, o projeto soviético de um "capitalismo sem capitalistas", relativamente autônomo a respeito do sistema mundial dominante (AMIN apud RECALDE, 2009, p. I66, tradução nossa).

Acrescenta-se a essas observações de Amin a formação do Movimento dos Países Não Alinhados (MNA), em I96I, que foi um desdobramento do encontro de Bandung em 1955, e teve como principais lideranças Jawaharlal Nehru, Gamal Abdel Nasser, Sukarno, Josip Broz Tito e Chu En-Lai. É nesse espaço institucional que a ideologia terceiro-mundista se alastrou para os países periféricos. O Terceiro Mundo não se configurou enquanto uma instituição, ao contrário do Movimento dos Países Não Alinhados, mas sim como uma ideologia presente nos movimentos de libertação nacional na África, América do Sul, Ásia e mesmo nos EUA, por meio dos Panteras Negras ${ }^{14}$.

\footnotetext{
3 A posição do Partido Comunista Chinês era distinta quanto à definição da noção de Terceiro Mundo, já que incluía no Primeiro Mundo as duas superpotências, e no Segundo Mundo os países desenvolvidos. Em seu discurso proferido na ONU em 10 de abril de 1974, Deng Xiaoping assim definia essa divisão no mundo: "A julgar pelas mudanças nas relações internacionais, o mundo de hoje na verdade consiste em três partes, ou três mundos, que estão ao mesmo tempo interconectados e em contradição um com o outro. Os Estados Unidos e a União Soviética constituem o Primeiro Mundo. Os países em desenvolvimento da Ásia, África, América Latina e outras regiões constituem o Terceiro Mundo. Os países desenvolvidos, entre os dois [blocos], formam o Segundo Mundo (DENG, 1974, tradução nossa).

14 Para os Panteras Negras o Terceiro Mundo se encontrava, na formação social estadunidense, representado pelos negros, latinos e asiáticos: "O povo negro nos EUA é um povo colonizado em todos os sentidos do termo e a América branca é uma força imperialista organizada que mantém o povo negro sob as amarras coloniais [...;] o que precisamos é de uma revolução na metrópole branca e a libertação nacional para a colônia negra." (PANTERAS NEGRAS, 2017, p. 48)
} 
O terceiro-mundismo ${ }^{15}$ é o elemento agregador na ideologia nacionalista, e nessa articulação fundamenta-se o conteúdo de caráter revolucionário do discurso nacionalista que, no caso do peronismo, dará o tom ao socialismo nacional dos anos I960 e i970.

Fanon foi certamente a maior expressão intelectual que encarnou a ideologia terceiro-mundista em um movimento alternativo ao bloco capitalista e ao bloco socialista, não obstante ele demarcar estrategicamente a necessidade da aproximação política do Terceiro Mundo com as formações sociais socialistas no período pós-colonial. Em sua máxima - e derradeira - obra, Os condenados da Terra, Fanon demarca claramente essa posição terceiro-mundista e sua aproximação com a perspectiva socialista, ainda que, segundo ele, essas novas formações sociais não devessem ficar atreladas a um dos dois blocos em disputa, mas sim buscar a construção de um novo socialismo:

Geralmente, pensava-se que era chegada a hora, para o mundo e singularmente para o Terceiro Mundo, de escolher entre o sistema capitalista e o sistema socialista. Os países subdesenvolvidos, que utilizaram a competição feroz que existe entre os dois sistemas para garantir o triunfo de sua luta de libertação nacional, devem, entretanto, recusar instalarem-se nessa competição. $\mathrm{O}$ Terceiro Mundo não deve se contentar em definir-se em relação a valores que o precederam. Os países subdesenvolvidos, ao contrário, devem esforçar-se para criar valores que lhes sejam próprios, métodos, um estilo que lhes sejam específicos. [...] A exploração capitalista, os trustes e monopólios são os inimigos dos países subdesenvolvidos. Em contrapartida, a escolha de um regime socialista, de um regime inteiramente voltado para o conjunto do povo, baseado no princípio de que o homem é o bem mais precioso, nos permitirá ir mais longe, mais harmoniosamente, tornando assim impossível essa caricatura de sociedade em que alguns detêm o conjunto dos poderes econômicos e políticos, em detrimento da totalidade social (FANON, 2006, p. II9).

Hernández Arregui foi o intelectual da corrente do socialismo nacional que mais enfatizou a noção de Terceiro Mundo no movimento peronista ${ }^{16}$. Em Peronismo y socialismo, ele afirma:

Não há um Terceiro Mundo incomunicável com os blocos capitalista e socialista. [...] Os países coloniais não escapam da influência do capitalismo e

\footnotetext{
15 Não havia um consenso absoluto sobre a noção de Terceiro Mundo entre as lideranças africanas, entre elas o dirigente marxista e pan-africanista de Gana Kwame Nkrumah. Embora reconheça que os países do Terceiro Mundo tornaram-se os "pontos quentes" da revolução mundial, Nkrumah discordava da homogeneidade que a noção de Terceiro Mundo conferia a essas distintas formações sociais: "o conceito de Terceiro Mundo é ilusório. Na verdade, está em grande parte dependente do imperialismo. A luta contra o imperialismo tem lugar no interior e exterior do mundo imperialista: trata-se de uma luta entre o socialismo e o capitalismo, e não entre um chamado Terceiro Mundo e o imperialismo. $\bigcirc$ eixo do problema é a luta de classes. Além disso, é impossível edificar o socialismo no mundo em vias de desenvolvimento isoladamente do sistema socialista mundial." (NKRUMAH, 2016, p. 91-92) Posição semelhante à de Nkrumah em relação à fragilidade do conceito de Terceiro Mundo, na medida em que este abarcaria distintas formações sociais e composições políticas antagônicas, é a de Debray (1977).

16 Sobre o impacto do terceiro-mundismo na intelectualidade argentina, veja o artigo de Albuquerque (2013)
} 
do socialismo. Do mesmo modo que as nações capitalistas e socialistas não podem desligar-se do círculo colonial. [...] O conceito de Terceiro Mundo, útil e até necessário para individualizarmos genericamente, interpretado de uma maneira interessada, pode servir às concepções mais reacionárias, que, com o pretexto do "terceiro-mundismo", o que em rigor propõem em benefício do imperialismo é excluir esses povos, mediante as chamadas "fronteiras ideológicas", do contexto internacional. O critério deve ser inverso. E por Terceiro Mundo deve entender-se uma categoria histórica que outorga plena vigência aos povos coloniais e os converte em carta decisiva na resolução do problema mundial (ARREGUI, I973, p. II, tradução nossa).

Vemos que, tanto no discurso de Fanon como no de Arregui, o Terceiro Mundo não era um ator neutro e indiferente quanto à Guerra Fria, entre os EUA e a URSS. A despeito de suas diferentes características e projetos autônomos quanto à luta anticolonial e anti-imperialista (sem falar na heterogeneidade entre essas formações sociais), o Terceiro Mundo era o palco central desse conflito, e exerceu um papel fundamental no jogo das relações do confronto político, econômico e ideológico entre esses dois blocos.

Cooke, distintamente de Arregui, optou por usar o termo terceira posição, que foi edificado por Perón no início da Guerra Fria, no final dos anos 1940. Até a primeira metade dos anos 1950 - antes do golpe de 1955 - , a terceira posição defendida por Cooke, não obstante ele ter um caráter latino-americanista e adotar uma intransigente oposição ao imperialismo estadunidense, não pactuava com o bloco socialista. Acusava também a URSS por sua posição imperialista, além de fazer uma acirrada crítica a uma "infiltração comunista" nos sindicatos (MAZZEO, 2005, p. 50). Contudo, depois da queda de Perón, sua posição política cada vez mais se radicalizou, seja na crítica que já vinha desferindo à burocracia sindical, seja na esquerdização de seu nacionalismo, que ficará ainda mais acentuado a partir da Revolução Cubana de 1959. O nacionalismo defendido por Cooke não é mais o veículo para o desenvolvimento industrial, mas sim a via argentina para o socialismo, além de ter incorporado a teoria marxista em seu discurso e nas suas análises de conjuntura. E a terceira posição internalizava a perspectiva do terceiro-mundismo, que representava a luta de libertação nacional em confronto tanto com o imperialismo quanto com a oligarquia argentina, que estava articulada com os interesses imperialistas. $\mathrm{O}$ peronismo tornou-se sinônimo de socialismo nacional, e significava a expressão máxima argentina da luta de libertação nacional, somando-se a outras lutas que estavam sendo travadas no Terceiro Mundo ${ }^{17}$.

\footnotetext{
1 "As revoluções socialistas e as lutas de libertação mundial de 1950 e 1960 marcaram seu pensamento e a maneira de participar na estruturação do movimento de libertação. Dessa maneira, foi modificando sua leitura do peronismo, interpretando-o por uma ótica cada vez mais marcadamente classista." (RECALDE, 2009, p. 216, tradução nossa) Para além da Revolução Cubana, a Revolução Argelina liderada pela FLN e a resistência vietnamita dirigida pela FNL foram marcantes nesse giro no pensamento de Cooke.
} 
peronismo constituído no final dos anos I940I9. Terceira posição é, para Cooke, sinônimo de Terceiro Mundo, pois associava diretamente a ideologia terceiro-mundista ao projeto nacionalista do peronismo (ou socialismo nacional). Numa entrevista concedida em Havana para a revista Che, em agosto de I96I, comentou a polarização entre os blocos hegemônicos e criticou a posição da direita argentina, que tratava dessa questão de forma reducionista, pois teria de optar obrigatoriamente por um dos lados desse conflito:

A terceira posição é, precisamente, o contrário. Significa não ter compromissos com os blocos mundiais, estar em liberdade de tomar decisões mais convenientes aos interesses nacionais. Significa ter critério próprio para apreciar cada feito e cada atitude. [...] Em outras palavras, em cada momento e circunstância, nosso terceirismo consiste em opinar livremente, não nos somarmos ao coro dos que veem nos Estados Unidos a potência reinante. [...] $\mathrm{O}$ terceirismo foi uma forma de não sermos absorvidos pelo imperialismo ianque (COOKE, 2009, p. 85, tradução nossa) ${ }^{20}$.

19 Perón, em seus últimos discursos e entrevistas, ressaltava essa associação do Terceiro Mundo com a terceira posição. No entanto, a sua noção de Terceiro Mundo era ampla, já que incluía todas as formações sociais, à exceção das duas potências, os EUA e a URSS. Numa entrevista em novembro de 1973 a um jornalista alemão ocidental, surpreendido com a definição dada por Perón sobre o Terceiro Mundo, por este incluir no conceito a Alemanha e a Europa, já que economicamente não seriam países caracterizados pela pobreza, Perón disse: "esse é o conceito econômico. O conceito político é que o Terceiro Mundo está composto pelos países que não estão sob o domínio do imperialismo estadunidense ou do imperialismo russo." (PERÓN, 2009, p. 96, tradução nossa) Numa mensagem lida em Argel na Conferência dos Países Não Alinhados, em setembro de 1973, Perón associava a sua terceira posição com as bandeiras do Terceiro Mundo: "Frente a nós se levantam triunfantes o demoliberalismo e o coletivismo do marxismo dogmático internacional, alargando a sombra de suas alas imperialistas, ameaçando os povos do mundo que, angustiados, sofrem no silêncio da impotência a escravidão econômica da pressão imperialista ou, em seu padrão, o avanço ideológico reacionário sustentado pela pressão da força ou da violência. [...] Assim foi que nos decidimos por criar as novas bases de uma terceira posição, que nos permitiu oferecer a nosso povo outro caminho, que não o dirija à exploração e à miséria. [...] Toda a filosofia da terceira posição se encontra inscrita na doutrina justicialista e perfeitamente delineada em milhares de realizações da nossa etapa de governo, nas conquistas sociais, gremiais e culturais de um povo que soube manter destemida sua lealdade a esses princípios durante os 18 anos de cruenta luta, banhados com o sacrifício de muitos irmãos mortos, torturados e presos." (PERÓN, 2009, p. 100-101, tradução nossa) Mais adiante, num discurso pronunciado em abril de 1974, a associação da terceira posição com - Terceiro Mundo é explicitada por Perón: "Há um Terceiro Mundo que não obedece nem a um nem a outro dos imperialismos dominantes, e esse Terceiro Mundo é grande. Recordo que em 1945 lancei pela primeira vez a ideia de um Terceiro Mundo, quer dizer, a terceira posição. Naquela época 'não havia forno para os pães', em virtude de que havia se finalizado a Segunda Guerra Mundial e os vencedores impunham condições. Mas se passaram mais de 25 anos, e hoje dois terços do mundo fazem sentir a sua voz numa entidade organizada, os imperialismos vão cair em si. Ninguém jamais se levantou contra o mundo inteiro, e esse deve ser o caminho que tenderemos a seguir." (PERÓN, 2009, p. 126-127, tradução nossa)

20 Numa carta dirigida a Perón datada de 18 de outubro de 1962, Cooke dizia que a terceira posição retomava essa questão da não neutralidade da terceira posição em relação à luta anticolonial: "a terceira posição não é mais atitude de um país isolado e que não queira ser recrutado para a Guerra Fria. É a política de um núcleo de países que têm diferentes regimes político-sociais, mas problemas básicos comuns e coincidências fundamentais na posição internacional. Interpretam, ao mesmo tempo, os interesses de outras nações afro-asiáticas que têm menor liberdade de ação para determinar, ainda que tenham abandonado a condição colonial. Ademais, o tercerismo implica independência perante os blocos — capitalista e comunista —, mas não 'equidistância', porque a liberdade de decisão se traduz em posições consequentes de anti-imperialismo." (COOKE, 2007, p. 564, tradução nossa) 
Para Cooke, o peronismo seria uma ideologia/movimento que sintetizava o nacionalismo anti-imperialista, a oposição à oligarquia agrária e ao liberalismo e a incorporação das lutas de libertação nacional travadas no Terceiro Mundo. O peronismo, ou socialismo nacional, delimitaria uma oposição tenaz ao bloco no poder das classes dominantes, sobretudo da fração hegemônica que representava os interesses da oligarquia e do imperialismo. Entretanto, Cooke também traçaria outra linha de demarcação, mas desta vez interna ao próprio movimento peronista: tratava-se da direita peronista, representada pela burocracia sindical que se tornou, a partir do exílio de Perón em I955, a principal referência e porta-voz desse movimento. E dessa burocracia sindical a principal expressão era Augusto Vandor, que nos anos I96o lançou a palavra de ordem "Peronismo sem Perón". Devido a sua capacidade de negociador, que se iniciou no final dos anos 1940, Vandor alçou o mais alto grau da liderança da Confederação Geral do Trabalho (CGT). Desde o início dos anos 1960, Cooke já vinha construindo uma oposição à burocracia sindical, e a ruptura se consumou a partir da aproximação de Vandor com o governo do general Onganía, constituído depois do golpe de Estado contra o governo de Arturo Illia em 1966 ${ }^{21}$. É com base nessa aproximação da ala vandorista com o governo militar que Cooke escreveu Informe a las bases, que se dirigia à militância peronista para denunciar a traição da burocracia sindical ao movimento.

Para Cooke, além de a burocracia sindical não ter apoiado os movimentos de libertação nacional do Terceiro Mundo nem manifestado em nenhum momento qualquer solidariedade a Cuba, faltava a ela uma política de poder, já que sua atuação se restringia no máximo à política eleitoral (COOKE, 20II, p. 258). Para a burocracia sindical, a política se resumiria a puro "pragmatismo" e, consequentemente, ela era incapaz de liderar as massas. Segundo Cooke, em sua conferência dada em Córdoba em I964, "o burocrata não serve como dirigente porque, em definitivo, não se considera parte da massa; atua por ela, talvez para ela, mas não com ela" (COOKE, 2009, p. I37, tradução nossa).

O peronismo, com efeito, é um significante com diversos e opostos significa$\operatorname{dos}^{22}$, e isso fica nítido no movimento peronista, com as palavras de ordem "Perón, Evita, la patria peronista" ou "Perón, Evita, la patria socialista". Se para a burocracia sindical o peronismo se reduz à própria encarnação física e simbólica de Perón e a um projeto nacionalista, distributivista e pragmático, o qual resultou em acordos com o governo Onganía e também na aproximação com setores da direita nacionalista, para Cooke e a esquerda peronista o nacionalismo tem como objetivo a superação neocolonial e a materialização de um movimento de massas em direção ao socialismo nacional.

\footnotetext{
Sobre Perón e o peronismo, veja Protto (1988), Zanatta (2009), Pirro (2009) e Larraquy (2010).

Para Laclau (2011, p. 68), um significante pode ter ambiguidades: tanto uma sobredeterminação quanto uma subdeterminação de significados impediriam que estes fossem fixados plenamente. Porém, esse caráter flutuante do significante não faz dele vazio. E acrescento: o conjunto contraditório das interpelações da ideologia peronista resultou na constituição de diferentes sujeitos que se reconheciam no peronismo, ora graças à revitalização de um nacionalismo patriótico limitado ao combate das desigualdades por meio da distribuição de renda e políticas sociais, além da industrialização nacional, ora por conta da formação de uma política de massas condutora do processo revolucionário antiimperialista e socialista.
} 
Para Cooke (200II, p. 223), o peronismo "foi o mais alto nível de consciência a que chegou a classe trabalhadora argentina"23. Mas o seu limite se encontrou na falta de uma teoria necessária para reajustar a visão desse movimento político e adequá-lo para as contradições presentes na conjuntura da década de 1960. Ao se referir às massas como sujeito protagonista no processo político argentino, Cooke compreende que o peronismo é um movimento policlassista (COOKE, 2009, p. II9) composto de diferentes frações de classes, não sendo redutível ao operariado urbano. Contudo, se o movimento é policlassista, a ideologia peronista não teria, a seu ver, um caráter plural, já que se trataria de um movimento aglutinador para a formação de um programa político nacionalista e popular em direção ao socialismo.

Cooke, num artigo publicado em I966, estabeleceu uma linha de demarcação entre o que ele definiu como peronismo revolucionário e a sua antítese, a "burocracia peronista":

O peronismo é, por sua composição social e por suas lutas, revolucionário por essência. [...] O que chamamos de "burocracia peronista" é, em síntese, uma camada dirigente que opera com os mesmos valores do inimigo, e é incapaz, portanto, de conduzir as bases à tomada de poder, sem o qual não há saída nem para as classes trabalhadoras nem para o país, pois já entramos numa etapa em que não há nacionalismo burguês, e em que a revolução social e de libertação nacional não são objetivos diferenciáveis, mas sim dois aspectos de um mesmo processo indivisível (COOKE, 2009, p. 245, tradução nossa).

Essa distinção com relação à direita peronista ainda inclui outro elemento: o emprego da violência revolucionária para a construção do socialismo nacional; veremos isso na seção seguinte.

\section{A VIOLÊNCIA POLÍTICA REVOLUCIONÁRIA COMO PRÁXIS TRANSFORMADORA}

A violência política como meio de alcançar um objetivo, no caso, realizar uma revolução de caráter nacional-popular e construir um Estado e uma sociedade revolucionários, esteve presente em diversas organizações políticas no século XX, e tal projeto encontrou o seu auge entre os anos 1950 e I980, principalmente nas guerras de libertação nacional dos países do Terceiro $\mathrm{Mundo}^{24}$. A problemática da violência política revolucionária foi um dos elementos centrais do pensamento de Cooke no final dos anos I950, e se acentuou com a Revolução Cubana, de 1959, e a argelina, de 1962. Esse é um aspecto da sua obra que o diferencia de outros intelectuais peronistas de esquerda, como Arregui, Abelardo Ramos e Puiggrós, que não trataram dessa pro-

\footnotetext{
Noutra passagem de La lucha por la liberación nacional, Cooke afirma que "Perón é o símbolo que congrega a resistência ao regime; Perón no país, ou perto do país, é um fator de desenvolvimento da consciência e da combatividade revolucionária das massas." (COOKE, 2011, p. 214, tradução nossa)

24 No Brasil, há poucos estudos sobre a problemática da violência revolucionária do ponto de vista teórico. Uma referência nesse tema é o livro de Saint-Pierre (2000).
} 
blemática e também não advogaram esse meio como forma de o peronismo retomar o poder e iniciar o processo revolucionário.

Com a aproximação de Cooke ao pensamento marxista, nos anos $1950^{25}$, a sua proposição de ruptura política pelo meio insurrecional tomou corpo. Ademais, a via violenta para a derrubada do regime instalado em 1955 (e depois em 1966, com a ascensão do general Onganía por meio de um golpe de Estado) indicava que a revolução também teria um programa socialista transformador. As posições de Cooke, portanto, iam ao encontro de outras lideranças políticas e intelectuais que advogavam a revolução socialista pela via insurrecional (numa oposição à posição pacifista do Partido Comunista da União Soviética - PCUS - em 1958, que veio a influenciar as diretrizes dos chamados partidos comunistas "oficiais"), como Mao Tsé-tung, Fidel Castro, Ernesto "Che" Guevara, Ho Chi Minh, Vo Giap, Amílcar Cabral, Kwame Nkrumah e Frantz Fanon.

A teoria marxista deu substância à prática política revolucionária dos autores listados acima, fossem ou não militantes de organizações comunistas ${ }^{26}$. A problemática da violência política estava presente em Marx e Engels, distintamente do que apregoa Arendt (1994, p. 19) em sua tentativa de demarcar uma diferença entre Marx e Sartre. Embora Sartre, em seu prefácio ao livro de Fanon, enfatize o papel da violência nas ações humanas, tanto Marx como Engels entendiam que a violência presente no modo de produção capitalista por intermédio do Estado só poderia ser rompida através de uma revolução que derrubasse o Estado por ações violentas. Como afirmam Marx e Engels em O manifesto do Partido Comunista:

Ao traçarmos as fases mais gerais do desenvolvimento do proletariado, seguimos de perto a guerra civil mais ou menos oculta no seio da sociedade burguesa vigente até o ponto em que estala abertamente uma revolução e o proletariado, pela derrubada violenta da burguesia, lança os fundamentos do seu próprio domínio (MARX; ENGELS, I982, p. II7) ${ }^{27}$.

O marxismo está inserido na tradição maquiaveliana do realismo político, que reconhece a violência estar inserida na prática política. Como observa Maquiavel

\footnotetext{
25 A aproximação de Cooke à obra de Marx aplica-se, sobretudo, aos textos do jovem Marx, nos quais há uma centralidade das categorias homem e alienação. Esse é um aspecto que o aproxima bastante de autores isebianos como Vieira Pinto, que também centrava suas análises sobre a questão nacional nas categorias homem e alienação.

26 Fanon nunca militou numa organização comunista, e a FLN da Argélia, ainda que defendesse um programa socialista, nunca teve como referência a teoria marxista. A sua aproximação com o marxismo foi por meio da obra de Sartre. Fidel, em 1959, se reivindicava um nacionalista revolucionário e antiimperialista, e sua aproximação com o marxismo veio em 1961; a fundação do Partido Comunista de Cuba (que congregou as várias organizações socialistas e comunistas pretéritas à revolução de 1959) foi em 3 de outubro de 1965. Já Ernesto Guevara, ainda que fosse marxista antes de se aproximar de Fidel, nunca militara no Partido Comunista da Argentina, e nutria certa simpatia pelo peronismo. Marx reconhece que a violência tem um papel decisivo no processo de transformação da história: "Tais métodos, como, por exemplo, o sistema colonial, baseiam-se, em parte, na violência mais brutal. Todos eles, porém, lançaram mão do poder do Estado, da violência concentrada e organizada da sociedade, para impulsionar artificialmente o processo de transformação do modo de produção feudal em capitalista e abreviar a transição de um para o outro. A violência é a parteira de toda sociedade velha que está prenhe de uma sociedade nova." (MARX, 2013, p. 821)
} 


\section{O pensamento de Cooke se insere nessa premissa, pois a violência não pode ser indiscriminada, e tampouco praticada sem uma base teórica. Nesse aspecto, Cooke vê tanto limites na burocracia peronista, por seu pacifismo pragmático, como também naqueles que recorrem à violência sem um programa sólido}

(198I), a política é a soma da virtù e da fortuna, e a virtù não somente exige a habilidade política em encarar as adversidades, mas também o uso da força quando se faz necessário. O príncipe (ou Estado) internaliza tanto a astúcia da raposa como a força do leão. Paradigmática disso é a analogia que Maquiavel faz da figura do centauro, que soma a inteligência com a força. $E$ o uso da violência não condiz com um desejo individual, mas sim com a defesa de um interesse coletivo. Em suma, há uma calculabilidade do uso da violência, em vez de seu uso indiscriminado na prática política ${ }^{28}$.

O pensamento de Cooke se insere nessa premissa, pois a violência não pode ser indiscriminada, e tampouco praticada sem uma base teórica. Nesse aspecto, Cooke vê tanto limites na burocracia peronista, por seu pacifismo pragmático, como também naqueles que recorrem à violência sem um programa sólido, provido de teoria. Como ele afirma em sua conferência realizada em Córdoba no ano de I964: "a violência sem fundamentos teóricos suficientes é também uma simplificação da realidade, supõe um expediente - o da violência - tirado do contexto revolucionário, desvinculado da luta de massas" (COOKE, 2009, p. I32, tradução nossa). Isso significa que as ações revolucionárias não devem se pautar por mero voluntarismo para a alteração da correlação de forças, sem o apoio das massas, sem fundamento teórico e sem base na realidade, o que resultaria numa violência inorgânica e anárquica.

A vanguarda guerrilheira, para Cooke, tem de estar cimentada nas massas, pois o guerrilheiro é também um sujeito político. E nesse aspecto a contribuição de Carl Schmitt a essa problemática foi fundamental em seu livro de 1963, Teoria do partisan, e teve como ponto de partida a definição de que a política estabelece uma distinção entre amigo e inimigo já desenvolvida em seu clássico $O$ conceito do político, de

28 "Quanto à reforma total e imediata da constituição política, quando há convicção geral de que ela é defeituosa, é difícil efetuá-la mesmo se o defeito é evidente, porque para isso os meios ordinários são insuficientes. Torna-se indispensável o recurso a métodos extraordinários — as armas e a violência. Antes de mais nada, o reformador deve apoderar-se do Estado, a fim de poder dele dispor à vontade." (MAQUIAVEL, 1982, p. 77) 
I932 $2^{29}$. O texto de Schmitt é pioneiro ao definir o guerrilheiro como um ator político presente no contexto pós-Segunda Guerra, haja vista a contribuição de Mao Tsé-tung e de Ernesto "Che" Guevara a esse tema por meio de suas publicações sobre a guerra popular e a guerra de guerrilhas. Para Schmitt, o guerrilheiro, além de ser um combatente irregular, demonstra um intenso engajamento político, o que o diferencia de ladrões e criminosos comuns, cujos motivos estão voltados para o enriquecimento pessoal (SCHMITT, 2009, p. I62) 30. $^{\circ}$

A guerra é a expressão máxima da inimizade absoluta, pois, sendo a continuação da política por outros meios, segundo a fórmula de Clausewitz ${ }^{31}$, seu objetivo máximo é o aniquilamento e a neutralização total do inimigo ${ }^{32}$. No entanto, há dois tipos de guerra, de acordo com Mao Tsé-tung ${ }^{33}$ : a guerra justa e a guerra injusta. Para Mao, existem não somente as leis gerais da guerra, mas também as específicas da guerra revolucionária (MAO, 20IIa, p. 296). Segundo Mao, "a guerra, que existe desde que surgiram a propriedade privada e as classes, é a forma suprema de luta para resolver contradições, em determinada etapa do seu desenvolvimento, entre classes, nações, Estados ou grupos políticos" (MAO, 20IIa, p. 296). Em relação à distinção entre as guerras justas e as guerras injustas, Mao afirma em seu opúsculo Problemas estratégicos da guerra revolucionária na China que

a guerra, esse monstro que faz com que os homens se matem, acabará por ser eliminada pelo próprio desenvolvimento da sociedade humana. [...] A história só registrou duas espécies de guerras: as guerras justas e as guerras injustas. [...] Todas as guerras contrarrevolucionárias são injustas, todas as guerras revolucionárias são justas (MAO, 20IIa, p. 302).

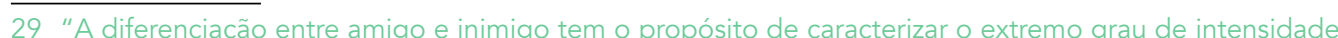
de uma união ou separação, de uma associação ou desassociação, podendo existir na teoria e na prática, sem que, simultaneamente, tenham que ser empregadas todas aquelas diferenciações morais, estéticas, econômicas ou outras [...;] inimigo não é concorrente ou o adversário em geral. Tampouco é inimigo o adversário privado a quem se odeia por sentimentos de antipatia. Inimigo é apenas um conjunto de pessoas em combate ao menos eventualmente, i.e., segundo a possibilidade do real, e que se defronta com um conjunto idêntico. Inimigo é somente o inimigo público, pois tudo o que se refere a um conjunto semelhante de pessoas, especialmente a todo um povo, se torna, por isso, público." (SCHMITT, 2009, p. 28-30, grifos originais)

30 "Teremos que chegar à conclusão inevitável de que o guerrilheiro é um reformador social que empunha as armas respondendo ao protesto irado do povo contra os seus opressores e que luta para mudar o regime social que mantém todos os seus irmãos desarmados na ignomínia e na miséria." (GUEVARA, 1980, p. 16)

31 De acordo com Clausewitz, "vemos, pois, que a guerra não é somente um ato político, mas um verdadeiro instrumento político, uma continuação das relações políticas, uma realização destas por outros meios [...;] a intenção política é o fim, enquanto que a guerra é o meio, e não se pode conceber o meio independentemente do fim." (CLAUSEWITZ, 1979, p. 87-88)

32 "A guerra é sempre uma luta em que ambos os contendores tratam de aniquilar um ao outro. Recorrerão, então, a todos os truques possíveis para conseguir esse resultado, além da força." (GUEVARA, 1980, p. 18)

33 "O maior prático da guerra revolucionária da atualidade converteu-se simultaneamente em seu mais célebre teórico: Mao Tsé-tung." (SCHMITT, 2009, p. 204) Para Schmitt, Mao pode ser definido como o "novo Clausewitz", pois deu continuidade consequente e sistemático-consciente aos conceitos do oficial do Estado-maior prussiano. Dentre os textos de Mao sobre a problemática da guerra revolucionária podemos citar Problemas estratégicos da guerra revolucionária na China (1936), Problemas estratégicos da guerra de guerrilhas contra o Japão (1938), Sobre a guerra prolongada (1938) e Problemas da guerra e da estratégia (1938). 


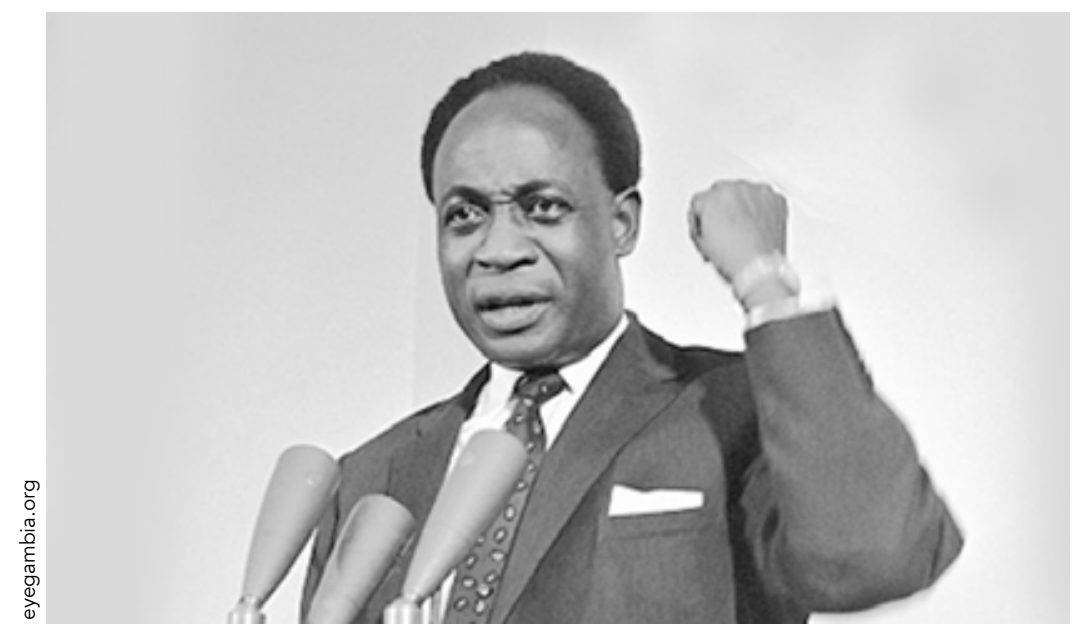

Uma das principais expressões do marxismo africano, Kwame Nkrumah, presidente de Gana entre 1960 e 1966, também advogava o uso da violência revolucionária como primado da prática política para os movimentos de libertação nacional

A guerra revolucionária traz consigo o elemento da violência, pois uma ruptura política não se faz, de acordo com os teóricos marxistas e terceiro-mundistas, de forma gradual e pacífica, pela qual se chegaria a um consenso entre as distintas e antagônicas posições. Como diz Mao em seu texto "Relatório sobre uma investigação feita no Hunan a respeito do movimento camponês",

uma revolução não é o convite para um jantar, a composição de uma obra literária, a pintura dum quadro ou a confecção dum bordado; ela não pode ser assim tão refinada, calma e delicada, tão branda, tão afável, tão cortês, comedida e generosa. Uma revolução é uma insurreição, é um ato de violência pelo qual uma classe derruba outra (MAO, 20IIa, p. 28).

Revolução e violência são elementos indissociáveis para os teóricos marxistas e terceiro-mundistas nesse contexto em que as formações sociais coloniais e neocoloniais foram marcadas pelas revoluções de libertação nacional. Se os sistemas colonial e neocolonial são opressores em razão de suas estruturas políticas, ideológicas e econômicas, nas quais se sustentam os regimes opressores e aliados ao imperialismo, a alternativa de mudança radical não passa pelos canais institucionais democráticos, mas sim pelo recurso à violência armada como forma de derrubar os regimes e iniciar um processo de transformação profunda. A obra de Cooke, que se constituiu a partir da segunda metade dos anos I950, é um reflexo desse contexto em que vivia o Terceiro Mundo. Com a queda de Perón em 1955 e o malogro da resistência armada peronista ao regime de Aramburu e Rojas, no qual o peronismo foi colocado na clandestinidade, a opção se encontrava nas experiências dos países periféricos que recorreram à luta armada organizada com apoio popular, a exemplo das experiências chinesa, vietnamita, argelina e cubana.

Assim sendo, a libertação nacional e a revolução social só poderiam ser concretizadas pela violência revolucionária. Paradigmática no continente africano foi a Revolução Argelina, liderada pela FLN, que teve impacto direto nas demais lutas de 
libertação nacional do continente. Fanon, sem dúvida, foi a principal expressão intelectual desse contexto de defesa do uso da violência revolucionária, e ganhou notoriedade internacional com o lançamento da sua obra Os condenados da terra, publicada em 196I. Distintamente da afirmação de Arendt (1994, p. 49) - de que Fanon seria um "glorificador" da violência ${ }^{34}$ —, a violência, para o pensador martinicano, é estrutural, pois se faz presente no cotidiano do colonizado desde o seu nascimento até o seu falecimento. É uma violência não somente física, mas também cultural e econômica, a qual leva o colonizado à perda de sua identidade. Como observa Fanon (2006, p. 69), o colonizado apenas se sente livre enquanto sonha.

Assim como o conceito de trabalho para Marx e Engels (2007) em A ideologia alemã é a práxis mediadora que leva à transformação do homem, pois, à medida que, ao transformar um objeto por meio do trabalho, o homem também sofre transformações cognitivas nessa relação dialética, a violência é a práxis libertadora do colonizado. É uma violência reativa ao poder colonial, que, em última instância, leva à transformação do colonizado em um novo sujeito. Conforme Fanon afirma:

Para o colonizado, essa violência representa a práxis absoluta. [...] Trabalhar, é trabalhar para a morte do colono. A violência assumida permite, ao mesmo tempo, aos desgarrados e aos proscritos do grupo voltar, reencontrar o seu lugar, reintegrar-se. A violência é assim compreendida como a mediação real. O homem colonizado se liberta na e pela violência. Essa práxis ilumina o agente, porque lhe indica os meios e o fim (FANON, 2006, p. I04).

Para Fanon, a nação pós-colonial é forjada pelas armas. Sua identidade e projeto nacional se constituíram pela violência revolucionária e reativa à violência do colonizador, e adquirem um papel totalizante na construção de um novo sujeito liberto das amarras do jugo colonial. Essa posição de Fanon fica explícita nesta passagem:

Essa práxis violenta é totalizante, pois cada um se faz um elo violento da grande corrente, do grande organismo violento surgido como reação à violência primeira do colonialista. Os grupos se reconhecem entre si e a nação

34 Há nesse texto de Arendt uma oposição sistemática às posições de Fanon. Ao classificá-lo como um "glorificador" da violência, Arendt não se aprofunda sobre a violência cotidiana dos colonizados, e tampouco sobre a ausência de canais institucionais para uma saída pacífica de diversas formações sociais que estavam submetidas à colonização. Nenhum comentário, por exemplo, sobre o apartheid sul-africano, nem sobre as ações terroristas do esquadrão da morte francês, a OAS (Organisation Armée Secrète), na Argélia. Ao abordar a violência do movimento negro estadunidense, particularmente o Partido dos Panteras Negras, e a influência de Fanon sobre essa organização, não cita uma vez sequer as ações da KKK e de outras organizações supremacistas brancas e fascistas nos EUA. Arendt também inclui entre os "glorificadores da violência" Sorel e Pareto. Sorel, em Reflexões sobre a violência, ao tratar da violência, a define como um mito, i.e., o não real, e apresenta como veículo dessa violência mítica a greve geral e não a insurreição armada. Sobre Pareto, os erros de Arendt são mais gritantes. Pareto analisa a violência como um fato social presente nas sociedades. Sua posição sobre a violência no mundo político-social é a mesma de um geofísico sobre um terremoto, pode-se não gostar do fato, mas se trata de um fenômeno objetivo. E, diferentemente do que afirma Arendt (1994, p. 53), a plutodemocracia não é uma "forma mista de governo", mas sim a circularidade das elites em qualquer forma de governo democrático, mais calcada na astúcia do que na força. Sobre a questão da violência e da plutocracia em Pareto, veja Etapas do pensamento sociológico, de Raymond Aron, e Dialética do irracionalismo: Pareto e seu confronto com Marx, de Nelson Mello e Souza. 
futura é indivisa. A luta armada mobiliza o povo, isto é, ela o joga numa única direção de mão única. A mobilização da massa, quando se realiza por ocasião da guerra de libertação, introduz em cada consciência a noção de causa comum, de destino nacional, de história coletiva. Assim, a segunda fase, a da construção da nação, é facilitada pela existência dessa argamassa, trabalhada com sangue e cólera. [...] Durante o período colonial, convidava-se o povo a lutar contra a opressão. Depois da libertação nacional, convidam-no a lutar contra a miséria, o analfabetismo, o subdesenvolvimento. A luta, afirma-se, continua. $O$ povo verifica que a vida é um combate interminável. A violência do colonizado unifica o povo. [...] A violência na sua prática é totalizante, nacional (FANON, 2006, p. III-II2) ${ }^{35}$.

A violência revolucionária ganha, com efeito, a partir das afirmações de Fanon, um caráter constitutivo nas novas formações sociais oriundas do colonialismo. Não que isso não estivesse presente em Mao, mas em Fanon a violência política ganha uma centralidade pela sua práxis transformadora, já que ela é formadora de um novo sujeito (de um "novo homem", no dizer de Fanon). Suas teses causaram um grande impacto, pois sintetizavam o momento vivido pelo Terceiro Mundo, que estava atravessado por uma pluralidade de revoluções de libertação nacional.

Uma das principais expressões do marxismo africano, o ex-presidente de Gana Kwame Nkrumah, também advogava o uso da violência revolucionária como primado da prática política para os movimentos de libertação nacional, e, distintamente de Fanon, demarcava claramente como objetivo das formações sociais pós-coloniais o socialismo. Em seu livro escrito em 1970 durante o seu exílio, Luta de classes na África, deixa bem clara essa posição:

Embora não haja dogmas estabelecidos rigorosamente quanto à revolução socialista, já que a história não se repete, a experiência provou que, nas condições da luta de classes, a revolução socialista não se pode realizar sem recorrer à violência. Porque as elites privilegiadas não cederão o poder a não ser que sejam obrigadas; mesmo quando aceitam efetuar reformas, não cederão nunca apenas porque sua posição está ameaçada. Somente a ação revolucionária as poderá derrubar. [...] Porque a libertação e a unificação da África não podem estar dependentes de um consentimento, de preceitos morais ou de uma conquista moral. É somente recorrendo às armas que a África poderá se livrar dos últimos vestígios de colonialismo, imperialismo e neocolonialismo e se libertará e se unirá ao socialismo (NKRUMAH, 20I6, p. 88-89; 95).

Posição semelhante à de Fanon e Nkrumah é a de Amílcar Cabral, dirigente revolucionário da Guiné-Bissau e de Cabo Verde. Não há alternativa ao combate ao imperialismo e ao colonialismo que não seja por meio da violência. Em A arma da

35 Noutra passagem, Fanon afirma: "cada colonizado em armas é um fragmento da nação agora viva" (FANON, 2006, p. 156). 
teoria, Cabral demarca essa posição do recurso à violência revolucionária no tópico "O papel da violência":

Os fatos dispensam-nos de usar palavras para provar que o instrumento essencial da dominação imperialista é a violência. Se aceitarmos o princípio de que a luta de libertação nacional é uma revolução, e que ela não acaba no momento em que se iça a bandeira e se toca o hino nacional, veremos que não há nem pode haver libertação nacional sem uso da violência libertadora, por parte das forças nacionalistas, para responder à violência criminosa dos agentes do imperialismo. Ninguém duvida de que, sejam quais forem as suas características locais, a dominação imperialista implica um estado de permanente violência contra as forças nacionalistas. Não há povo no mundo que, tendo sido submetido ao jugo imperialista (colonialista ou neocolonialista), tenha conquistado a sua independência (nominal ou efetiva) sem vítimas. O que importa é determinar quais formas de violência devem ser utilizadas pelas forças de libertação nacional, para não só responderem à violência do imperialismo, mas também para garantirem, através da luta, a vitória final da sua causa, isto é, a verdadeira independência nacional (CABRAL, I980, p. 38).

Como podemos ver, as posições de Fanon, Cabral e Nkrumah convergem para o uso da violência revolucionária, pela impossibilidade de uma saída pacífica para a descolonização nos países do Terceiro Mundo. Ademais, a violência revolucionária não somente garantiria a construção de uma formação social independente para o processo de transição, mas também forjaria um "novo homem" identificado com esse processo revolucionário.

Formou-se nesse contexto dos anos 1960 um bloco de organizações revolucionárias marxistas e nacionalistas influenciadas pela Revolução Cubana (especialmente na figura de Guevara), além da chinesa (tendo como principal referência os escritos militares de Mao Tsé-tung), em antagonismo com as organizações tradicionais da esquerda, como os partidos comunistas e socialistas que ainda apostavam numa saída pacífica, seja nas colônias, seja nas formações sociais dependentes (majoritariamente dirigidas por ditaduras militares, ou governos autoritários), como Argentina, Brasil, Uruguai, Nicarágua etc., situadas na América Latina.

Cooke foi a expressão máxima na Argentina dessa perspectiva revolucionária terceiro-mundista, e em muitos aspectos há semelhança de suas posições com as de Fanon. Não sabemos se Cooke teve acesso à obra de Fanon, pois não há nenhuma citação da obra do autor martinicano em seus textos. Sua semelhança com Fanon também pode ser percebida ao não definir a priori a forma organizacional que conduzirá a revolução. Será o partido, como defendia $\mathrm{Mao}^{36}$, ou o foco guerrilheiro,

36 Em Problemas da guerra e da estratégia, escrito em novembro de 1938, Mao afirmava: "Todos os comunistas devem compreender a seguinte verdade: 'O poder político nasce do fuzil.' O nosso princípio é o seguinte: o partido comanda o fuzil, e jamais permitiremos que o fuzil comande o partido." (MAO, 2011b, p. 367) 
como apregoava Debray ${ }^{37}$, baseado nas análises de Che Guevara?

Para Cooke, não seria nem o partido nem o foco guerrilheiro, e sim o movimento peronista que daria a priori a sustentação para o movimento armado revolucionário. $\mathrm{O}$ movimento se constitui antes do próprio partido ${ }^{38}$ e do exército popular, tendo em vista a limitação do partido quando este se burocratiza, ou se limita apenas ao jogo eleitoral, e, por seu turno, um exército revolucionário sem base popular estará fadado ao fracasso. Cooke percebia que o peronismo ia além da figura individual de Perón, e o seu limite encontrava-se na pluralidade do movimento, daí a necessidade de canalizar a vertente revolucionária do peronismo pela via armada. Contudo, a figura de Perón seria necessária para essa aglutinação, pois ela é "o símbolo que congrega a resistência ao regime [..., é um fator de desenvolvimento da consciência e da combatividade revolucionária das massas" (COOKE, 20II, p. 2I4, tradução nossa), e não um obstáculo à luta armada (COOKE, 20II, p. 229).

Cooke não esteve alheio à resistência peronista iniciada a partir do golpe de Estado liderado por Aramburu e Rojas contra Perón em 1955. Cooke esteve vinculado à resistência malograda liderada pelo general Valle em I956, o que resultou na sua prisão, sua fuga e seu exílio no Chile e, posteriormente, em Cuba. Nesse período, Cooke se aproximou do Exército de Libertação Nacional-Movimento Peronista de Libertação, mais conhecido pela denominação Uturuncos, que constituiu uma guerrilha em Tucumán na virada dos anos 1950 para 1960 e foi derrotada pelo governo Frondizi. Ao retornar à Argentina em 1963, fundou juntamente com a sua companheira Alicia Eguren a Ação Revolucionária Peronista (ARP). A ARP atuou no movimento peronista ao constituir núcleos combativos no movimento estudantil e nos sindicatos, além de ter exercido influência na juventude cristã terceiro-mundista (MAZZEO, 2005, p. 59-60). Em 1967, Cooke retornou a Cuba — representando a ARP — para participar da Olas (Organização Latino-Americana de Solidariedade), e afirmou que a única saída política voltada à ruptura com o sistema neocolonial e à implementação do socialismo só poderia ser pela luta armada, e, embora Cuba fosse a referência, o modelo da guerrilha rural não poderia ser aplicado mecanicamente, já que cada formação social possuía características e contradições próprias ${ }^{39}$.

A defesa da violência revolucionária está presente nas suas três principais obras da década de 1960: Informe a las bases, La lucha por la liberación nacional e Apun-

\footnotetext{
37 "O que unifica é a guerra e seus objetivos imediatos. [...] Assim, pouco a pouco, esse pequeno exército faz a unidade tendo por base todos os partidos, e à medida que cresce e obtém as primeiras vitórias. Finalmente, o futuro exército do povo engendrará o partido de que ele deveria ser teoricamente o instrumento. No essencial, o partido é ele. [...] A guerrilha é a vanguarda política in nuce, e apenas do seu desenvolvimento pode surgir o partido." (DEBRAY, s.d., p. 84; 94).

38 "O peronismo é mais que um partido. Não o dissolvem por decreto, nem o amansam por intimidação." (COOKE, 2011, p. 169, tradução nossa)

39 Em sua intervenção na Olas em 1966, Cooke afirmou: "toda revolução é um feito único e não uma repetição; mas estabelece e demonstra certos princípios que são patrimônio das lutas subsequentes. Assim, o importante é que em Cuba se demonstrou que o exército regular pode ser derrotado; não se pode pretender que se dê uma receita sobre como fazê-la em cada caso particular. [...] A luta armada muda qualitativamente os termos do enfrentamento político-social no seio de um determinado país." (COOKE, 2009, p. 255-256, tradução nossa)
} 


\section{É falsa a oposição entre a violência \\ e a não violência, pois, para o \\ pensador argentino, "a questão \\ é se a violência dos opressores \\ deve ser combatida pela violência libertadora dos oprimidos"}

tes para la militancia, além de outros textos redigidos nesse contexto. Primeiramente, Cooke distingue a violência revolucionária da violência reacionária do aparato estatal (COOKE, 20II, I2I). O regime oligárquico-liberal deve ser desalojado pela violência, já que se mantém pela violência. Para Cooke, "a violência do ato revolucionário popular não é revanchista nem se exerce contra as ideias e os homens, senão contra os obstáculos que impedem a plena liberdade do homem e a plena soberania da nação" (COOKE, 20II, p. I90, tradução nossa).

Em segundo lugar, como foi dito mais acima, a teoria revolucionária compreende a teoria da violência, "para que não ocorram os desastres da violência sem teoria do aventureirismo ou se incorra em erros de conceito como os do reformismo" (COOKE, 20II, p. 218, tradução nossa).

Em terceiro, é falsa a oposição entre a violência e a não violência, pois, para o pensador argentino, "a questão é se a violência dos opressores deve ser combatida pela violência libertadora dos oprimidos" (COOKE, 20II, p. 219, tradução nossa). A violência dos oprimidos, semelhantemente à visão de Fanon, carrega uma moral própria e transformadora. De acordo com Cooke,

o revolucionário não deprecia a moral: despreza a ética do regime para substituí-la pela ética da solidariedade revolucionária. A violência revolucionária não é como a do regime, uma violência mecânica em si mesma, ela tem base ideológica e moral. [...] É violência contra os inimigos dos seres humanos, ou seja, é amor aos homens que se traduz em ódio a quem causa sua desgraça (COOKE, 20II, p. 219, tradução nossa).

Há, com efeito, semelhanças no significado da violência revolucionária entre Cooke e Fanon, como já observara Alvarez. Essas semelhanças se dão tanto no caráter da formação de um "novo homem" por meio da práxis da violência revolucionária, que carrega consigo a formação de uma nova ética revolucionária, como também da construção de uma nova nação. A nação que pensam Cooke e Fanon é "o povo em armas, rebelado contra a opressão. [...] Na luta feroz no presente, recriamos a cultura nacional, a consciência de nossa história comum (ALVAREZ, 20I3, p. 310, 32I, tradução nossa)". 
Depois do falecimento prematuro de Cooke, em I968, as posições dele foram amplamente incorporadas pela militância peronista revolucionária ${ }^{40}$, como as FAP (que incorporaram parte da ARP), os Montoneros (a principal organização peronista revolucionária), as FAR (de origem marxista) e os Descamisados ${ }^{41}$. Os anos que se seguiram a seu falecimento foram o momento do embate mais agudo travado entre as organizações revolucionárias e os aparatos repressivos do Estado argentino. Além da luta armada, essas organizações tinham como eixo o projeto do socialismo nacional identificado com as lutas de libertação nacional. Essas organizações - juntamente com o Exército Revolucionário do Povo (ERP, de origem trotskista, tornando-se depois guevarista) - tiveram um importante papel no combate aos governos Onganía e Lanusse. O governo Lanusse acabou por recuar e facultou o retorno de Perón à Argentina, em 1973. Contudo, o governo de Perón (que durou de I2 de outubro de 1973 até $\mathrm{I}^{\mathrm{o}}$ de julho de $\mathrm{I} 974$ ) se dissociou completamente do projeto de socialismo nacional defendido por Cooke, ao dar maior peso à direita peronista ${ }^{42}$ liderada por José López Rega, Isabel Martinez, Lorenzo Miguel e Norma Kennedy, resultando na cisão da esquerda peronista com o governo Péron no dia $\mathbf{I}^{\mathrm{O}}$ de maio de $1974^{43}$. Mesmo com a derrota dessas organizações para o regime militar instalado em março de 1976 , o legado nacionalista e antiliberal de Cooke permaneceu vivo no seio do movimento peronista,

40 Sobre a influência de Cooke na esquerda peronista que se formou entre os anos 1960 e 1970 , veja o artigo de Caruso (2017).

41 Das organizações armadas peronistas, os Montoneros tiveram a maior projeção, tanto pelos seus feitos militares como também por terem se tornado uma organização de massas por meio da Juventude Peronista, e conseguiram eleger diversos representantes para o Legislativo e Executivo durante seu período de legalidade. A origem dos Montoneros se deu inicialmente na militância católica de direita (muitos de seus membros militaram no Movimento Nacionalista Tacuara, de corte fascista), e, com a ascensão dos Sacerdotes para o Terceiro Mundo, que tiveram como uma de suas principais lideranças o padre Carlos Mugica, boa parte da militância dessa organização migrou para o campo do peronismo revolucionário e criou a organização Montoneros. Há uma ampla bibliografia sobre os Montoneros, com destaque para os estudos de Gillespie (2008), Langhi (2008) e Donatello (2010).

42 Sobre a direita peronista, veja Larraquy (2007).

43 Laclau fez uma precisa síntese sobre a ideologia peronista. Primeiramente, se o elemento populista na ideologia peronista consistiu na radicalização das interpelações populares antiliberais, o discurso peronista consistia não somente nessas interpelações como também em sua articulação com um discurso que procurava circunscrever o confronto com a oligarquia liberal aos limites impostos pelo projeto de classe que definia o regime: o desenvolvimento do capitalismo nacional. Segundo, se o peronismo teve êxito em constituir uma linguagem popular-democrática unificada em nível nacional, isso se deveu à homogeneidade social da Argentina, pela ausência de campesinato, predomínio absoluto da população urbana, amplo desenvolvimento da média e pequena burguesias e desenvolvimento do sindicalismo operário em nível nacional. Terceiro, o apoio da classe operária ao peronismo foi preservado mesmo depois da derrocada deste, em 1955. E, por fim, se o antagonismo das interpelações populares só se desenvolveu dentro dos limites tolerados pelo governo peronista, enquanto este existiu, foi impossível continuar impondo esses limites uma vez proscrito o peronismo e iniciada a reorganização de seus quadros de baixo para cima. À medida que o liberalismo, restaurado em 1955, foi revelando a sua incapacidade de absorver as demandas democráticas das massas, passando a basear-se, cada vez mais, na repressão, o antagonismo potencial das interpelações populares conseguiu se desenvolver plenamente. Como afirma Laclau "a ideologia popular tornou-se cada vez mais antiliberal e, nos setores mais radicalizados, passou a fundir-se com o socialismo. 'Socialismo nacional' foi a fórmula cunhada no decorrer desse processo. A volta do peronismo ao poder, em 1973, provou isso com clareza: fracassaram as diferentes tentativas no sentido de voltar atrás o relógio da história e de articular a ideologia populardemocrática de modo a tornar-se assimilável pela burguesia. O regime de Isabel Perón caiu em um caos repressivo, sem haver conseguido nenhuma forma de articulação estável entre interpelações populares e ideologia burguesa." (LACLAU, 1979, p. 196-197) 
fortalecendo-se com a ascensão do governo Kirchner, que revitalizou o peronismo de esquerda e acabou por isolar a corrente direitista liderada por Menem. E é nesse contexto que a obra de Cooke despertou, e vem despertando, cada vez maior interesse entre os militantes e os estudiosos do fenômeno do peronismo, que se mantém como a maior corrente política na Argentina nos últimos 75 anos.

\section{CONSIDERAÇÕES FINAIS}

O objetivo desse artigo foi recuperar a contribuição do pensamento de Cooke, um autor praticamente desconhecido no Brasil ${ }^{44}$, não obstante ele pertencer a um conjunto de autores identificados com as lutas anticoloniais, notadamente Frantz Fanon e Mao Tsé-tung.

Cooke, com efeito, não pode ser enquadrado como um autor pós-colonial ou decolonial, mas sim anticolonial e anti-imperialista. Como vimos ao longo deste artigo, Cooke defendeu no movimento peronista o projeto nacional-popular (em oposição ao nacionalismo conservador), e assim fortaleceu a tendência de esquerda do peronismo. Sua radicalização discursiva no movimento peronista demarcava explicitamente a defesa de um "socialismo nacional", afinado com as lutas de libertação nacional presentes no chamado Terceiro Mundo, e a defesa do uso da violência revolucionária como forma de luta para a derrubada do regime oligárquico-liberal. Nesse aspecto, a posição de Cooke ia ao encontro da defendida pelas diversas organizações da esquerda revolucionária, especialmente as que estavam situadas nos países do chamado Terceiro Mundo, e que adotaram a luta armada com base nos exemplos triunfantes ocorridos na China, Cuba e Argélia.

Ainda que as suas teses sobre a defesa da luta armada possam ser questionadas na atual conjuntura histórica, é inegável a atualidade de sua crítica aos limites do liberalismo, da sua visão de "latino-americanidade" e da sua compreensão de que o peronismo encarnava na formação social argentina o principal movimento de massas e de resistência ao projeto liberal. E isso foi marcante no início deste século, com o protagonismo do casal Kirchner, que recuperou o legado da esquerda peronista em oposição ao projeto neoliberal e isolou a direita peronista representada por Menem desde os anos 1990, e nesse balanço de forças a esquerda peronista se firmou como herdeira do legado iniciado em 1945 por Juan Domingo e Evita Perón. Desse modo, o legado de Cooke ao peronismo permanece vivo e atual diante o quadro conflituoso que continua em vigor na formação social argentina.

\footnotetext{
* Doutor em Sociologia pelo Instituto Universitário de Pesquisas do Rio de Janeiro (luperj). Professor associado de Ciência Política da Universidade Federal do Rio de Janeiro (UFRJ). Autor do livro A favor de Althusser. Colaborador das revistas Princípios e Crítica Marxista, entre outras. E-mail: luizpmotta63@gmail.com
}

Texto recebido em 29 de julho de 2021; aprovado em 30 de julho de 2021. 
ALBUQUERQUE, Germán. O terceiro-mundismo no campo cultural argentino: uma sensibilidade hegemônica (1961-1987). Tempo, v. 19, n. 35, 2013, p. 211-228. Disponível em: <www.scielo.br/scielo. php?script=sci_arttext\&pid=S1413-77042013000200012\&lng=en\&nrm=iso\&tlng=pt ISSN 14137704>. Acesso em: 13 mar. 2021.

ALVAREZ, Gonzalo Pérez. Frantz Fanon, John William Cooke y la creación heroica. A Contracorriente, v. 11, n. 11, p. 306-321, 2013. Disponível em: <https://acontracorriente.chass.ncsu.edu/index.php/ acontracorriente/article/view/694>. Acesso em: 13 mar. 2021.

ARENDT, Hannah. Sobre a violência. Rio de Janeiro: Relume Dumará, 1994.

ARREGUI, Hernández. Peronismo y socialismo. Buenos Aires: Corregidor, 1973.

CABRAL, Amílcar A arma da teoria. Rio de Janeiro: Codecri, 1980.

CARUSO, Valeria A. La forja de la izquierda peronista como cultura política a través de la trayectoria de John W. Cooke. Páginas, v. 9, n. 20, p. 169-192, 2017. Disponível em: <https://revistapaginas.unr. edu.ar/index.php/RevPaginas/article/view/265/html>. Acesso em: 15 mar. 2021.

CLAUSEWITZ, Carl von. Da guerra. São Paulo; Lisboa; São Paulo, Martins Fontes, 1979.

COOKE, John William. Acción parlamentaria. In: DUHALDE, Eduardo Luis (comp.). Obras completas. Buenos Aires: Colihue, 2007a. t. 1.

Artículos periodísticos, reportages, cartas y documentos. In: DUHALDE, Eduardo Luis (comp.). Obras completas. Buenos Aires: Colihue, 2009. t. 3.

Correspondencia Perón-Cooke. In: DUHALDE, Eduardo Luis (comp.). Obras completas. Buenos Aires: Colihue, 2007b. t. 2.

Peronismo y revolución. In: DUHALDE, Eduardo Luis (comp.). Obras completas. Buenos Aires: Colihue, 2011. t. 4.

DEBRAY, Régis. A crítica das armas. Lisboa: Seara Nova, 1977.

Revolução na revolução?. São Paulo: Centro Editorial Latino Americano [s.d.].

DENG Xiaoping. Speech by chairman of the delegation of the People's Republic of China, Deng Xiaoping, at the special session of the U.N. General Assembly. In: Marxists Internet Archive, 1974. Disponível em: <www.marxists.org/reference/archive/deng-xiaoping/1974/04/10.htm>. Acesso em: 29 mar. 2021.

DONATELLO, Luis Miguel. Catolicismo y Montoneros: religión, política y desencanto. Buenos Aires: Manantial, 2010.

FANON, Frantz. Os condenados da terra. Juiz de Fora: Editora UFJF, 2006.

FIRMENICH, Mario Eduardo. Mario Firmenich, comandante dos Montoneros argentinos (e inimigo público ${ }^{\circ} 1$ da $\mathrm{CI}$ ) faz autocrítica da guerrilha. [Entrevista concedida a] Fernando Morais. Status, São Paulo, n. 78, p. 53-68, jan. 1981.

FEINMANN, José Pablo. John W. Cooke: el peronismo revolucionario. Buenos Aires: Capital Intelectual, 2006.

FERREIRA, Jorge (Org.). O populismo e sua história. Rio de Janeiro: Civilização Brasileira, 2017.

; REIS, Daniel Aarão (Org.). Nacionalismo e reformismo radical: 1945-1964. Rio de Janeiro: Civilização Brasileira, 2007.

FRANCO, Maria Sylvia Carvalho. O tempo de ilusões. In: CHAUÍ, Marilena (Org.). Ideologia e mobilização popular. São Paulo: Paz e Terra, 1978.

GALASSO, Norberto. ¿Qué es el socialismo nacional?. Rosario: Germinal Ediciones, 2010.

GILLESPIE, Richard. Soldados de Perón: historia crítica sobre los Montoneros. Buenos Aires: Sudamericana, 2008.

GOLDAR, Ernesto. John William Cooke y el peronismo revolucionario. Buenos Aires: Editores de América Latina, 2004.

GUERREIRO RAMOS, Alberto. O problema nacional do Brasil. Rio de Janeiro: Saga, 1960.

Mito e verdade da revolução brasileira. Florianópolis: Insular, 2016. 
GUEVARA, Che. A guerra de guerrilhas. São Paulo: Edições Populares, 1980.

LACLAU, Ernesto. Emancipação e diferença. Rio de Janeiro: Eduerj, 2011.

Política e ideologia na teoria marxista. São Paulo: Paz e Terra, 1979.

LANGHI, Esteban. Montoneros-Cámpora: un encuentro histórico. Rosario, Libros del Sur, 2008.

LARRAQUY, Marcelo. De Perón a Montoneros: historia de la violencia política en la Argentina (19451973). Buenos Aires: Aguillar, 2010.

López Rega: el peronismo y la Triple A. Buenos Aires: Punto de Lectura, 2007.

MAQUIAVEL, Nicolau. Comentários sobre a primeira década de Tito Lívio. Brasília, Editora UNB, 1982.

O Príncipe. Rio de Janeiro: Civilização Brasileira, 1981.

MAO Tsé-tung. Obras escolhidas. São Paulo: Alfa-Omega, 2011a. v. 1.

Obras escolhidas. São Paulo: Alfa-Omega, 2011b. v. 2.

MARX, Karl. O Capital: crítica da economia política. Livro I. São Paulo: Boitempo, 2013.

; ENGELS, Friedrich. A ideologia alemã. São Paulo: Boitempo, 2007.

136.

O manifesto do Partido Comunista. In: Obras escolhidas. Lisboa: Avante, 1982.v. 1 pp. 106-

MAZZEO, Miguel. John Wiliam Cooke en dos tiempos: nacionalismo, socialismo y unidad latinoamericana. In: p. 47-62. (comp). Pensar a John William Cooke. Buenos Aires: Manuel Suárez Editor, 2005.

MOTTA, Luiz Eduardo. A política do Guerreiro: nacionalismo, revolução e socialismo no debate brasileiro dos anos 1960. Organizações \& Sociedade, Salvador, v. 17, n. 52, p. 85-101, 2010.

NKRUMAH, Kwame. Luta de classes na África. São Paulo: Nova Cultura, 2016.

PANTERAS NEGRAS. Todo poder ao povo. São Paulo: Nova Cultura, 2017.

PERÓN, Juan Domingo. America Latina, ahora o nunca. Buenos Aires: Punto de Encuentro, 2009.

PIRRO, Julio César Melon. El peronismo después del peronismo. Buenos Aires: Siglo XXI, 2009.

POULANTZAS, Nicos. Poder político e classes sociais. Campinas: Editora Unicamp, 2019.

PROTTO, Eduardo. Perón, peronismo y peronistas. Buenos Aires: Lainza, 1988.

RECALDE, Aritz. El pensamiento de John William Cooke en las cartas a Perón: 1956-1966. Buenos Aires: Nuevos Tiempos, 2009.

SAINT-PIERRE, Héctor Luis. A política armada: fundamentos da guerra revolucionária. São Paulo: Unesp, 2000

SCHMITT, Carl. O conceito do político. Teoria do partisan. Belo Horizonte: Del Rey, 2009.

SILVA, Gustavo Santos da. O centenário de John William Cooke: trajetória de um peronista revolucionário. In: ENCONTRO INTERNACIONAL HISTÓRIA \& PARCERIAS, 2., 2019, Rio de Janeiro. Anais... Rio de Janeiro: Anpuh, 2019. Disponível em: <www.historiaeparcerias2019.rj.anpuh.org/resources/ anais/11/hep2019/1569882785_ARQUIVO_440cd67311777d52bf620e1fa270883c.pdf>. Acesso em: 3 ago. 2021.

UGARTE, Manuel. La patria grande. Buenos Aires: Capital Intelectual, 2010.

WEFFORT, Francisco. O populismo na política brasileira. São Paulo: Paz e Terra, 1986.

ZANATTA, Loris. Breve história del peronismo clásico. Buenos Aires: Sudamericana, 2009. 